\title{
Genetic susceptibility to juvenile idiopathic arthritis in Iranian children
}

\author{
Reza Shiari ${ }^{1} 2^{*}$, Shirin Farivar ${ }^{3}$, Elham Hadia ${ }^{3}$ \\ From 18th Pediatric Rheumatology European Society (PReS) Congress \\ Bruges, Belgium. 14-18 September 2011
}

\section{Background}

Juvenile idiopathic arthritis (JIA) is the most common chronic rheumatic disease in children. It is a clinical diagnosis in a child, less than 16 years of age with arthritis for at least 6 weeks duration and exclusion of other causes of arthritis.

\section{Aims}

This study was comprised of Iranian children with oligoarthritis and rheumatoid factor negative (RF) polyarthritis subtypes of juvenile idiopathic arthritis (JIA) to determine the association of HLA-DRB1 alleles in Iranian population.

\section{Methods}

HLA-DRB1 alleles were investigated in 33 Iranian children with oligoarthritis and RF negative polyarthritis JIA and compared with 45 healthy controls. HLA typing was performed by PCR with sequence specific primers in either of the two groups and followed by direct detection of HLA polymorphism by sequence analysis in patient group.

\section{Results}

HLA-DRB1*11 was found to be the most frequent allele associated with oligoarthritis and RF negative polyarthritis JIA in Iran followed by DRB1 *08. The frequencies of HLA-DRB1"04 and "13 were not significantly different in both groups.

\section{Conclusions}

We concluded that there was a significant difference in allele frequencies between patients and control group

\footnotetext{
* Correspondence: shiareza@yahoo.com

${ }^{1}$ Shahid Beheshti University of Medical Sciences, Mofid Children Hospital, Tehran-Iran

Full list of author information is available at the end of the article
}

that may help in predicting the susceptibility to oligoarthritis and rheumatic factor negative polyarthritis JIA.

\section{Author details}

${ }^{1}$ Shahid Beheshti University of Medical Sciences, Mofid Children Hospital, Tehran-Iran. ${ }^{2}$ Pediatric Infectious Research Center (PIRC), Tehran-Iran. ${ }^{3}$ Faculty of Biosciences, Shahid Beheshti University, GC. Tehran-Iran.

Published: 14 September 2011

\section{doi:10.1186/1546-0096-9-S1-P103}

Cite this article as: Shiari et al:: Genetic susceptibility to juvenile idiopathic arthritis in Iranian children. Pediatric Rheumatology 20119 (Suppl 1):P103.
Submit your next manuscript to BioMed Central and take full advantage of:

- Convenient online submission

- Thorough peer review

- No space constraints or color figure charges

- Immediate publication on acceptance

- Inclusion in PubMed, CAS, Scopus and Google Scholar

- Research which is freely available for redistribution

Submit your manuscript at www.biomedcentral.com/submit

\section{() Biomed Central}

